University of Nebraska - Lincoln

DigitalCommons@University of Nebraska - Lincoln

USDA National Wildlife Research Center - Staff Publications
U.S. Department of Agriculture: Animal and Plant Health Inspection Service

February 2003

\title{
Baiting blackbirds (Icteridae) in stubble grain fields during spring migration in South Dakota
}

\author{
G. M. Linz \\ USDA/APHIS/WS National Wildlife Research Center, george_m_linz@yahoo.com
}

G.A. Knutsen

North Dakota State University, Fargo, Department of Biological Sciences

H.J. Homan

USDA-APHIS-Wildlife Services

W.J. Bleier

North Dakota State University, Fargo, Department of Biological Sciences

Follow this and additional works at: https://digitalcommons.unl.edu/icwdm_usdanwrc

Part of the Environmental Sciences Commons

Linz, G. M.; Knutsen, G.A.; Homan, H.J.; and Bleier, W.J., "Baiting blackbirds (Icteridae) in stubble grain fields during spring migration in South Dakota" (2003). USDA National Wildlife Research Center -Staff Publications. 243.

https://digitalcommons.unl.edu/icwdm_usdanwrc/243

This Article is brought to you for free and open access by the U.S. Department of Agriculture: Animal and Plant Health Inspection Service at DigitalCommons@University of Nebraska - Lincoln. It has been accepted for inclusion in USDA National Wildlife Research Center - Staff Publications by an authorized administrator of DigitalCommons@University of Nebraska - Lincoln. 


\title{
Baiting blackbirds (Icteridae) in stubble grain fields during spring migration in South Dakota
}

\author{
G.M. Linz ${ }^{\mathrm{a}, *}$, G.A. Knutsen ${ }^{\mathrm{b}}$, H.J. Homan ${ }^{\mathrm{a}}$, W.J. Bleier ${ }^{\mathrm{b}}$ \\ ${ }^{a}$ US Department of Agriculture, Wildlife Services (USDA/APHIS/WS), National Wildlife Research Center, 2110 Miriam Circle, Suite B, Bismarck, \\ ND 58501, USA \\ ${ }^{\mathrm{b}}$ Department of Biological Sciences, Stevens Hall, North Dakota State University, Fargo, ND 58105, USA
}

Received 26 November 2001; accepted 3 April 2002

\begin{abstract}
Blackbirds (Icteridae) annually damage US\$5-8 million of ripening sunflower in the northern Great Plains. Baiting blackbirds with avicide-treated rice during spring migration might reduce the regional breeding population. In March and April 1996-1997, we simulated a baiting program in eastern South Dakota to compare attractiveness of rice-baited plots placed in fields of corn and soybean stubble. Blackbirds used plots in corn stubble more often than plots in soybean stubble and chose rice-baited plots over unbaited reference plots. We conclude that blackbirds can be successfully baited with avicide-treated rice placed in corn stubble. (C) 2002 Elsevier Science Ltd. All rights reserved.
\end{abstract}

Keywords: Avicide; Blackbirds; Sunflower

\section{Introduction}

In the United States, sunflower producers bear economic losses from blackbirds (Icteridae) averaging US\$5-8 million annually (Hothem et al., 1988), despite the use of several nonlethal pest management techniques (Linz and Hanzel, 1997). The majority of blackbird damage occurs in the northern Great Plains, which accounts for $>80 \%$ of US sunflower production (Bangsund and Leistritz, 1995). The red-winged blackbird (Agelaius phoeniceus), whose late-summer population exceeds 35 million (Stehn, 1989), might cause 50\% of the damage, while yellow-headed blackbirds (Xanthocephalus xanthocephalus) and common grackles (Quiscalus quisculus) cause the remainder of the damage (Homan et al., 1994). Knittle et al. (1996) showed that red-winged blackbirds staging in eastern South Dakota dispersed northwest to nesting areas in sunflower growing regions in the Dakotas and Prairie Provinces of Canada. Because of their proximity to sunflower during late summer, these birds probably cause a large portion of the sunflower damage recorded in the 4408

*Corresponding author. Tel.: +1-701-250-4469; fax: +1-701-250-

E-mail address: george.m.linz@aphis.usda.gov (G.M. Linz).
Dakotas (Linz and Hanzel, 1997). Reducing the size of this regional population during spring, prior to the breeding effort, might be an effective solution for reducing blackbird damage to sunflower.

The US Department of Agriculture's National Wildlife Research Center is evaluating the compound, DRC1339 (3-chloro- $p$-toluidine hydrochloride), to manage the northern Great Plains blackbird population (Linz et al. in press). In the 1980s and 1990s, research on DRC-1339 was initiated to manage blackbirds during late winter (Glahn and Wilson, 1992) and spring (Barras, 1996). During this time, brown rice emerged as the bait of choice for delivering a lethal dose of DRC1339 (Glahn and Wilson, 1992). Because effective and sound population management using DRC-1339-treated rice baits is contingent upon developing an efficient baiting strategy, we evaluated the attractiveness of brown rice scattered in small plots in fields of stubble corn and soybean in eastern South Dakota during March and April 1996 and 1997.

\section{Study area}

The study area was in Brookings, Miner, and Lake counties in eastern South Dakota. This area was chosen 
because it is considered to be the most northern region where migrating flocks of blackbirds are large enough to warrant a baiting programme (Sawin, 1999). Eastern South Dakota lies in the Coteau Des Prairies physiographic region in the Central Lowland province. The landscape is characterized by low, rolling hills and a variety of glacial till deposits; undrained lakes and small wetland basins abound (Johnson and Higgins, 1997). Formerly unbroken tall-grass prairie, the land now consists mainly of pasture and row crops. Shelterbelts and windbreaks divide expansive field crops and surround farmsteads and residential areas. Corn and soybean are the principal crops in eastern South Dakota, comprising $92 \%$ of the planted crops.

The long-term average temperature and precipitation during March and April in eastern South Dakota are $3.3^{\circ} \mathrm{C}$ and $4.6 \mathrm{~cm}$, respectively. During our 2-year study, temperatures and precipitation were below average for March and April. In 1996, the temperature averaged $0.2^{\circ} \mathrm{C}$ and precipitation was $1.3 \mathrm{~cm}$. In 1997, the average temperature was $0.9^{\circ} \mathrm{C}$ and precipitation was $3.8 \mathrm{~cm}$ (SDASS, 2000). An intense early spring storm entered the study area on 5-6 April 1997 and was followed by record cold $\left(-15^{\circ} \mathrm{C}\right)$ from April 8 to 12 .

\section{Methods}

In mid-March 1996, we selected three fields each of soybean and corn stubble located near blackbird roosts. We placed one pair of adjacent plots of equal size ( $\sim 1.1$ ha) in each field. One member of each pair was baited with brown rice; the other served as an unbaited reference. In mid-March 1997, we selected four fields of each crop, and the size of the plots was standardized at $0.8 \mathrm{ha}$. We applied $22.7 \mathrm{~kg}$ of brown rice once or twice per week using a seed broadcaster mounted on an allterrain vehicle. We marked the corners of each plot with colored stakes to assist the observers in delineating plot boundaries. We scanned the paired plots from a blind situated 3-m above ground level and mounted on a pickup truck parked about $25 \mathrm{~m}$ from the plots. After a 30-min period of quiet, a single observer recorded the species and numbers of blackbirds using the plots. Observation periods lasted $1 \mathrm{~h}$ with 1 -min counts alternating on each plot every 5 min ( 12 observations/ h). All observations were made by a pool of four trained observers. During periods of snow, rain, or wind $>32 \mathrm{~km} / \mathrm{h}$, observations were not conducted. In both years, the study ended when spring cultivation began.

In 1996, observations started on 21 March and ended on 26 April. We divided the daylight hours into four equal periods with the first observation starting within 30 min of the beginning of each time period. In 1997, observations began on 29 March (after snow had melted in the crop fields) and ended on 29 April. We divided daylight hours into two equal periods, with the first observation starting within $30 \mathrm{~min}$ of the beginning of each period. We eliminated the mid-day time strata in 1997 because bird activity was comparatively low in these strata during 1996.

We used blackbirds per minute of observation as the measurement unit for analyzing bird activity in the plots. A "bird/min" was defined as the number of members of a species present in the plot during a 1-min observation period (Knutsen, 1998).

Within each experimental year, we used Wilcoxon two-sample tests (Cody and Smith, 1997) to test the hypotheses that bird/min did not differ (1) between ricebaited and reference plots within crops, and (2) between rice-baited plots placed in fields of stubble corn and soybean.

\section{Results}

\subsection{Observations in 1996}

Four species of blackbirds [brown-headed cowbirds (Molothrus ater), red-winged blackbirds, common grackles, yellow-headed blackbirds] were observed during $150 \mathrm{~h}$ of timed observations. Red-winged blackbirds accounted for $98.2 \%$ of all bird/min (Table 1). The second and third most abundant species were common grackles $(1 \%)$ and yellow-headed blackbirds $(<1 \%)$, respectively. Blackbird activity in the plots placed in corn stubble peaked at over $2000 \mathrm{bird} / \mathrm{min}$ between 3 and 8 April, whereas blackbird activity in soybean stubble peaked at about $150 \mathrm{bird} / \mathrm{min}$ between 9 and 10 April. The number of blackbirds using the plots decreased rapidly after mid-April.

In corn stubble, blackbirds averaged $373 \mathrm{bird} / \mathrm{min}$ $(\mathrm{SE}=140.9)$ in rice-baited plots and $<1 \mathrm{bird} / \mathrm{min}$ $(\mathrm{SE}=0.1)$ in reference plots $(P<0.01)$. In soybean stubble, blackbirds averaged $41 \mathrm{bird} / \mathrm{min}(\mathrm{SE}=11.4)$ in

Table 1

Total bird/min/5-min interval for blackbirds in fields of stubble corn and soybean in eastern South Dakota during March and April 1996

\begin{tabular}{lrrrl}
\hline Species & $\begin{array}{l}\text { Bird/min } \\
\text { in corn } \\
\text { stubble }\end{array}$ & $\begin{array}{l}\text { Percent } \\
\text { of corn } \\
\text { stubble } \\
\text { total }\end{array}$ & $\begin{array}{l}\text { Bird/min in } \\
\text { soybean } \\
\text { stubble }\end{array}$ & $\begin{array}{l}\text { Percent of } \\
\text { soybean } \\
\text { stubble } \\
\text { total }\end{array}$ \\
\hline $\begin{array}{l}\text { Red-winged } \\
\text { blackbird }\end{array}$ & 339,564 & 99.7 & 40,380 & 96.7 \\
$\begin{array}{l}\text { Common } \\
\text { grackle }\end{array}$ & 324 & 0.1 & 820 & 2.0 \\
$\begin{array}{l}\text { Yellow-headed } \\
\text { blackbird }\end{array}$ & 516 & 0.2 & 533 & 1.3 \\
$\begin{array}{l}\text { Brown-headed } \\
\text { cowbird }\end{array}$ & 24 & $<0.1$ & 5 & $<0.1$ \\
\begin{tabular}{l} 
Total \\
\hline
\end{tabular} & 340,428 & 100 & 41,738 & 100 \\
\hline
\end{tabular}


Table 2

Total bird/min/5-min interval for blackbirds in fields of stubble corn and soybean in eastern South Dakota during March and April 1997

\begin{tabular}{lcccl}
\hline Species & $\begin{array}{l}\text { Bird/min } \\
\text { in corn } \\
\text { stubble }\end{array}$ & $\begin{array}{l}\text { Percent } \\
\text { of corn } \\
\text { stubble } \\
\text { total }\end{array}$ & $\begin{array}{l}\text { Bird/min in } \\
\text { soybean } \\
\text { stubble }\end{array}$ & $\begin{array}{l}\text { Percent of } \\
\text { soybean } \\
\text { stubble } \\
\text { total }\end{array}$ \\
\hline $\begin{array}{l}\text { Red-winged } \\
\text { blackbird }\end{array}$ & 3938 & 70.9 & 1272 & 93.5 \\
$\begin{array}{l}\text { Common } \\
\text { grackle }\end{array}$ & 436 & 7.9 & 10 & 0.7 \\
$\begin{array}{l}\text { Yellow-headed } \\
\text { blackbird } \\
\text { Brown-headed } \\
\text { cowbird }\end{array}$ & 973 & 17.5 & 63 & 4.6 \\
$\begin{array}{l}\text { Brewer's } \\
\text { blackbird }\end{array}$ & 155 & 2.8 & 15 & 1.1 \\
\begin{tabular}{l} 
Total \\
\hline
\end{tabular} & 5553 & 100 & 1361 & 100 \\
\hline
\end{tabular}

rice-baited plots and $6 \mathrm{bird} / \mathrm{min}(\mathrm{SE}=0.1)$ in reference plots $(P<0.01)$. Blackbird abundance was significantly greater in rice-baited plots in corn stubble than in soybean stubble $(P<0.01)$.

\subsection{7}

In addition to the four species recorded in 1996, Brewer's blackbirds (Euphagus cyanocephalus) were observed in 1997 (Table 2). Red-winged blackbirds accounted for $82 \%$ of all bird/mins, while yellow-headed blackbirds and common grackles made up $11 \%$ and $4 \%$, respectively. Blackbird abundance in the plots peaked during the third week of April, which was 10-14 days later than in 1996, and declined rapidly in late April.

In corn stubble, blackbirds averaged $5 \mathrm{bird} / \mathrm{min}$ $(\mathrm{SE}=0.9)$ in rice-baited plots and $1 \mathrm{bird} / \mathrm{min}(\mathrm{SE}=0.7)$ in reference plots $(P<0.01)$. In soybean stubble, they averaged $1 \mathrm{bird} / \mathrm{min}(\mathrm{SE}=0.3)$ in rice-baited plots and $<1 \mathrm{bird} / \mathrm{min}(\mathrm{SE}=0.1)$ in reference plots $(P<0.01)$. There was no statistical difference between blackbird use of rice-baited plots in corn and soybean $(P>0.1)$.

\section{Discussion}

Arrival and departure dates of blackbirds migrating through eastern South Dakota during our study were consistent with dates reported by the South Dakota Ornithologists Union (1991). In 1997, two early April snow storms covered the landscape and probably forced the birds to delay their migration and remain at their staging sites in more open areas. When the snow melted, blackbirds appeared to move quickly through South Dakota, accounting for the relatively low numbers of blackbirds recorded in the plots in 1997.

Our experiment demonstrated that in 1996 blackbirds strongly preferred corn stubble over soybean stubble.
No preference was shown for either crop in 1997. However, our study was only one of four projects conducted on feeding behaviors of free-ranging blackbirds in eastern South Dakota. Observations during the springs of 1993 (Linz et al., 1995), 1994-1995 (Barras, 1996), and 1998 (Sawin, 1999) indicated that blackbirds preferred to forage in corn stubble over all other cultivated grains, including soybeans. Thus, in four separate studies, blackbirds generally showed a preference for corn stubble. Blackbirds probably preferred foraging in corn stubble over soybean stubble because waste corn was more plentiful and palatable than waste soybean (Dabbert and Martin, 1994). Additionally, cornfields may have contained more weed seeds, which serve as an additional attractant (Linz et al., 1984).

We observed that blackbirds actively sought ricebaited plots when foraging in either kind of stubble. Based on the success of late winter baiting in the southern United States (Glahn and Wilson, 1992), rice might be ideally suited for blackbirds even during spring migration. Rice is a novel food in the northern Great Plains, however, and that necessitates prebaiting as an essential part of a successful baiting program.

We conclude that (1) blackbird numbers, especially numbers of red-winged blackbirds, generally peak during the first 2 weeks of April, but migration can be delayed by adverse weather, particularly late spring snows; (2) blackbirds are attracted to brown rice and thus it is an acceptable bait carrier; and (3) avicidetreated brown rice should be placed in stubble fields of corn to maximize efficiency.

\section{Acknowledgements}

R. Carlson and G. Nuechterlein reviewed earlier drafts of the manuscript. We thank B. Bonesteel, D. Bergman, B. Check, J. Jensen, T. Slowik, J. Tharman, and $\mathbf{J}$. Wendel for assistance with data gathering. R. Carlson and C. Doetkott provided statistical advice. Administrative support was provided by S. Kath, D. Reff, T. Tank, and J. Weisbeck. This research was funded jointly by the National Wildlife Research Center, a unit within the Wildlife Services Program of the United States Department of Agriculture, Animal Plant Health Inspection Service, and the Department of Biological Sciences at North Dakota State University.

\section{References}

Bangsund, D.A., Leistritz, F.L., 1995. Economic contribution of the United States sunflower industry. Agricultural Economics Report No. 327, North Dakota State University, Fargo, North Dakota, $154 \mathrm{pp}$. 
Barras, A.E., 1996. Evaluation of the efficacy of DRC-1339 for reducing spring migratory blackbird populations. M.S. Thesis, North Dakota State University, Fargo, North Dakota, 108pp.

Cody, R.P., Smith, J.K., 1997. Applied statistics and the SAS programming language, 4th Edition. Prentice Hall, New Jersey, $445 \mathrm{pp}$.

Dabbert, C.B., Martin, T.E., 1994. Effects of diet and ambient temperature on food choice of captive mallards. Southwest. Nat. $39,143-147$.

Glahn, J.F., Wilson, E.A., 1992. Effectiveness of DRC-1339 baiting for reducing blackbird damage to sprouting rice. Proc. East. Wildlife Damage Control Conf. 5, 117-123.

Homan, H.J., Linz, G.M., Bleier, W.J., Carlson, R.B., 1994. Dietary comparisons of adult male common grackles, red-winged blackbirds, and yellow-headed blackbirds in north central North Dakota. Prairie Nat. 26, 273-281.

Hothem, R.L., DeHaven, R.W., Fairazl, S.D., 1988. Bird damage to sunflower in North Dakota, South Dakota and Minnesota, 19791981. US Fish and Wildlife Technical Report 15, 11pp.

Johnson, R.R., Higgins, K.F., 1997. Wetland resources of eastern South Dakota. South Dakota State University and South Dakota Cooperative Fish and Wildlife Research Unit, Brookings, 102pp.

Knittle, C.E., Linz, G.M., Cummings, J.L., Davis Jr., J.E., Johns, B.E., Besser, J.F., 1996. Spring migration patterns of male redwinged blackbirds (Agelaius phoeniceus) from two migratory roosts in South Dakota and Minnesota. Am. Midl. Nat. 136, 134-142.
Knutsen, G.A., 1998. Avian use of rice-baited and unbaited stubble fields during spring migration in South Dakota. M.S. Thesis, North Dakota State University, Fargo, North Dakota, 160pp.

Linz, G.M., Hanzel, J.J., 1997. Birds and sunflower. Sunflower Science and Technology, American Society of Agronomy, Madison, Wisconsin, pp. 381-394.

Linz, G.M., Barras, A.E., Sawin, R.A., Bergman, D.L., Bleier, W.J., Spring migration phenology and habitat use of red-winged blackbirds in eastern South Dakota. Proceedings of the 20th Vertebrate Pest Conference, in press.

Linz, G.M., Vakoch, D.L., Cassel, J.F., Carlson, R.B., 1984. Food of red-winged blackbirds (Agelaius phoeniceus), in sunflower fields and corn fields. Can. Field-Nat. 98, 38-98.

Linz, G.M., Bergman, D.L., Bleier, W.J., 1995. Birds associated with blackbird spring feeding sites in South Dakota. Prairie Nat. 27, $11-15$.

Sawin, R.S., 1999. Habitat characteristics of spring blackbird roosts in eastern South Dakota. M.S. Thesis, North Dakota State University, Fargo, North Dakota, 92pp.

SDASS, 2001. South Dakota agriculture 2001. South Dakota Agricultural Statistics Service, Sioux Falls, South Dakota, $117 \mathrm{pp}$.

Stehn, R.A., 1989. Population ecology and management strategies for red-winged blackbirds. Bird Damage Research Report No. 432, US Department of Agriculture, Denver Wildlife Research Center, Denver, Colorado, $71 \mathrm{pp}$. 